\title{
Production response of lambs receiving creep feed while grazing two different pastures
}

\author{
S. Terblanche ${ }^{1}$, T.S. Brand ${ }^{1,2,3 \#}$, J.W. Jordaan ${ }^{1}$ \& J.C. van der Walt ${ }^{2}$ \\ ${ }^{1}$ Nelson Mandela Metropolitan University, George Campus: Saasveld, Private Bag X6531, George, 6530 \\ ${ }^{2}$ Elsenburg Agricultural Research Centre, Private Bag X1, Elsenburg, 7607 \\ ${ }^{3}$ Department of Animal Science, University of Stellenbosch, Stellenbosch 7600

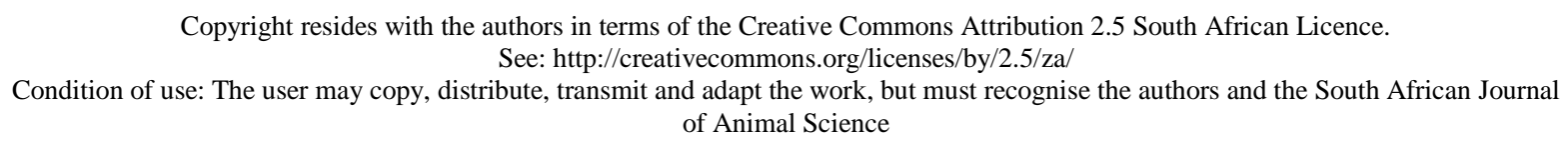

\begin{abstract}
The aim of the study was to determine the production responses of lambs receiving either creep feed or not while grazing two different pastures. The production of ewes within each treatment was also recorded. The study was conducted at both the Kromme Rhee and Langgewens Research Farms. At Kromme Rhee, sheep grazed kikuyu (Pennisetum clandestinum) pasture under irrigation. Dohne Merino $(n=47)$ ewes, with their lambs, were randomly allocated to four groups. At Langgewens, the sheep grazed medic (Medicago parrabinga) pastures under dry-land conditions. South African Mutton Merino ewes ( $\mathrm{n}=89$ ), with their lambs, were randomly divided into four groups. At Langgewens creep feed was provided at $200 \mathrm{~g} / \mathrm{lamb} / \mathrm{day}$ from the start of the study. This was increased by $100 \mathrm{~g} / \mathrm{lamb} /$ day every week up to a maximum of 600 g/lamb/day. At Kromme Rhee, creep feed was provided at 200 and 300 g/lamb/day for the first and second week, respectively. From week three creep feed was provided ad libitum. At both locations ewes and lambs were weighed once a week. Live weight data of lambs and ewes were analysed by means of a multifactor analysis of variance with treatment (creep feed or no creep feed) and birth status (single and twins) as main factors. Provision a creep feed at Langgewens significantly increased lamb weight, but had no effect on ewe live weight. The provision of creep feed At Kromme Rhee significantly increased lamb weight as well as ewe weight. At both locations, birth status had no effect on the production parameters for ewes or lambs.
\end{abstract}

Keywords: Creep feed, birth status, pastures, production response

"Corresponding author: tersb@elsenburg.com

\section{Introduction}

To produce lambs of the required market weight, optimum levels of feed are required for both ewes and lambs. Crop residues and certain predominantly grass pastures used for grazing lack nutrients to fulfil the requirements of the ewe and lamb (Weston \& Hogan, 1986; Aitchison, 1988). To overcome insufficient levels of nutrients and poor growth rates of lambs on cultivated pastures, management practices such as supplementation are of vital importance (De Villiers, 1991; Brand et al., 1999). Supplementation can be done by providing the lambs with creep feed, which may also be beneficial to the ewe because of the possible reduction in lactation demand (De Villiers, 1993).

Creep feeding may be incorporated into a production system, and have several possible advantages, such as the earlier development of the rumen and an increase in the utilisation of feed (De Villiers, 1997). This may result in obtaining a higher weaning weight (Coetzee, 2011). Providing lambs with creep feed may be more profitable when the level of grazing available to the ewe and lambs becomes limited (Brand et al., 1999).

This study was conducted to evaluate the production response of lambs receiving creep feed or not while grazing two different pastures, and the influence of creep feeding on the ewes' production. 


\section{Materials and Methods}

Two experiments were conducted on two different research farms in the Winter Rainfall Region of South Africa to determine the production response of lambs receiving creep feed or not, while grazing two different pastures. The farms were Langgewens ( $33^{\circ} 17^{\prime} \mathrm{S}, 18^{\circ} 42^{\prime} \mathrm{O}$ ) in the Swartland area and Kromme Rhee (33⒌'S, $18^{\circ} 50^{\prime} \mathrm{O}$ ) in the Cape Wine Lands area.

At Langgewens, the experiment consisted of 89 South African Mutton Merino ewes with lambs that were divided into four comparable groups (two experimental and two control groups). Each group was allocated to a 12 ha camp with medic (Medicago parrabinga) pastures cultivated under dry-land conditions.

At the start of the study, the lambs were, on average, one month of age and $200 \mathrm{~g} /$ day of creep feed was provided to the two experimental groups. This was increased by $100 \mathrm{~g} /$ day each week up to a maximum of $600 \mathrm{~g} / \mathrm{lamb} /$ day. The ewes and lambs were weighed on a weekly interval to determine the influence of creep feeding on the production lamb as well as their dams.

At Kromme Rhee a group of 47 Dohne Merino ewes with lambs was similarly divided into four comparable groups (two experimental and two control groups) and allocated to different camps of approximately 0.4 ha of irrigated kikuyu (Pennisetum clandestinum) pasture.

At the start of the study the lambs were on average $2 \frac{1}{2}$ months of age. Creep feed was provided at 200 $\mathrm{g} / \mathrm{lamb} /$ day to the experimental groups during the first week. This was increased to $300 \mathrm{~g} / \mathrm{day}$ in the second week and from week three creep feed was allocated ad libitum until the end of the study. The ewes and lambs were weighed once a week during the trial period.

Production data from both studies were analysed by multifactor of variance with treatment and birth status as main factors (Statgraphics Centurion, 2005).

\section{Results and Discussion}

Production results of the ewes and lambs for Langgewens are illustrated in Table 1. No significant interactions occurred and the data are presented as main factors only.

It is clear from Table 1 that there were no differences in weight between ewes whose lambs received creep or not. Brundyn (2002) and De Villiers et al. (2002) found similar results. According to these results, birth status (single/twins) of the lambs showed no significant difference $(P>0.05)$ on the live weight of the ewe over the experimental period.

Table 1 The difference in the start and end live weight $(\mathrm{kg}$, mean \pm SE) of ewes and their lambs that received creep feed or not, and the effect of birth status, while grazing medic pastures for eight weeks at the Langgewens Research Farm

\begin{tabular}{lcc}
\hline & Ewes & Lambs \\
\hline Effect of treatment & & \\
Creep & $7.56^{\text {ns }} \pm 0.63$ & $15.71^{\mathrm{a}} \pm 0.53$ \\
$\quad$ Control & $5.91^{\text {ns }} \pm 0.64$ & $12.22^{\mathrm{b}} \pm 0.53$ \\
Effect of birth status & & \\
$\quad$ Single & $6.01^{\text {ns }} \pm 0.46$ & $14.64^{\text {ns }} \pm 0.49$ \\
Twins & $7.46^{\text {ns }} \pm 0.77$ & $13.29^{\text {ns }} \pm 0.56$
\end{tabular}

\footnotetext{
${ }^{\mathrm{a}, \mathrm{b}}$ Denotes significant $(P<0.05)$ differences between treatments.

${ }^{\text {ns }}$ Denotes no significant $(P>0.05)$ differences between treatments.
}

Results from the study clearly show that the live weight of lambs that received creep feed differed ( $P$ $<0.01$ ) in weight (ca $3.5 \mathrm{~kg}$ ) over the trial period compared to those without. Brand et al. (1993; 1999) and Brundyn (2002) reported similar results. The birth status (single/twins) of the lambs showed no difference ( $P$ $>0.05$ ) on the weight of the lambs at the end of the experiment. These results are in contrast with long-term 
results from studies by Cloete et al. (1998) and Snyman \& Olivier (2002). They reported that birth status had a significant effect on the weaning weight of lambs.

Growth curves of both the ewes and lambs are presented in Figures 1(a) and (b), respectively. The live weight change (LWC) of ewes whose lambs received creep feeding or not, is illustrated in Figure 1(a). No differences $(P>0.05)$ were observed on the live weight of the ewes. Figure 1(b) illustrates the live weight change (LWC) of lambs that received creep or not over the experimental period. The lambs that received creep feed showed a larger difference in LWC from the fourth to the eighth week of the experimental period. An induction period could influence the effect of creep feed on the weight change of the lambs in the first four weeks. A $0 \%$ mortality rate occurred over the study period.

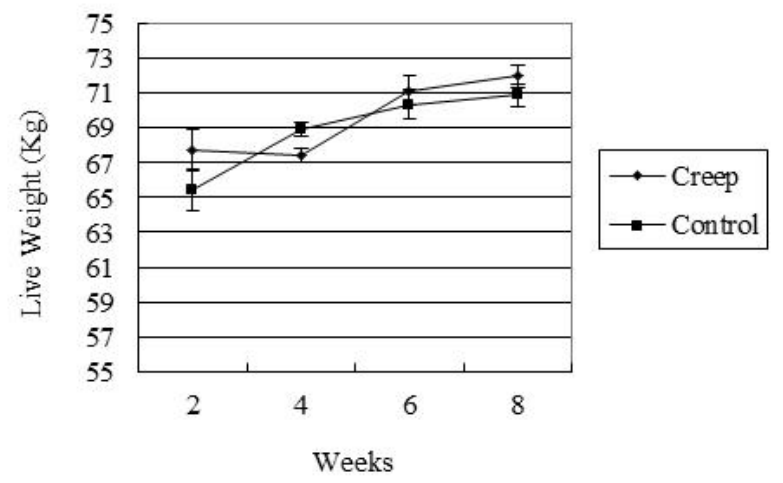

(a)

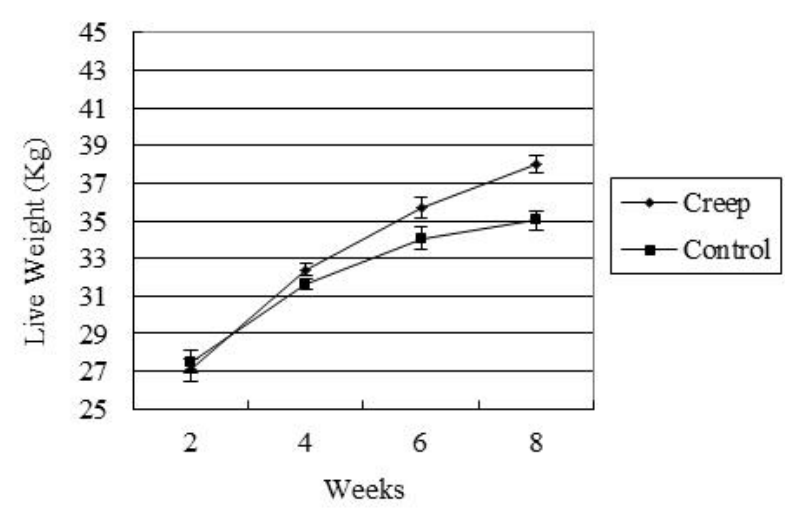

(b)

Figure 1 Live weight change of (a) ewes and (b) lambs grazing medic pastures at Langgewens Research Farm supplemented with or not a creep feed for lambs.

Production results of the lambs and ewes from Kromme Rhee are illustrated in Table 2. No significant interactions occurred in either experiment and data are presented as main factors only.

It is clear that the differences in the live weight of ewes whose lambs received creep feed differed ( $P$ $\leq 0.05$ ) from those that did not. This finding could support the opinion of De Villiers (1997) that allocating creep feeding to lambs leads to a decrease in the lactation demand of the ewes, enabling the ewes to regain condition quicker after the lactation phase. In contrast, Brundyn (2002) and De Villiers et al. (2002) stated that allocating creep to lambs had no effect on the weight changes of the ewes.

Table 2 The difference in weight (kg, mean \pm SE) of ewes and their lambs that received creep feed or no creep feed and the effect of birth status, when grazing kikuyu pastures for 10 weeks at the Kromme Rhee Research Farm

\begin{tabular}{lcc}
\hline & Ewes & Lambs \\
\hline Effect of treatment & & \\
Creep & $1.15^{\mathrm{a}} \pm 0.87$ & $11.87^{\mathrm{a}} \pm 0.86$ \\
Control & $-1.34^{\mathrm{b}} \pm 0.71$ & $3.11^{\mathrm{b}} \pm 0.74$ \\
Effect of birth status & $-0.67^{\mathrm{ns}} \pm 0.47$ & $7.41^{\mathrm{ns}} \pm 0.57$ \\
$\quad$ Single & $0.48^{\mathrm{ns}} \pm 1.02$ & $7.58^{\mathrm{ns}} \pm 0.98$ \\
Twins & \\
& \\
\hline${ }^{\mathrm{a}, \mathrm{b}}$ Denotes significant $(P \leq 0.05)$ differences between treatments. \\
${ }^{\mathrm{ns}}$ Denotes no significant $(P \geq 0.05)$ differences between treatment.
\end{tabular}


It is clear from Table 2 that the live weight of lambs that received creep feed differed $(P<0.01)$ in weight (ca $8.8 \mathrm{~kg}$ ) from those that did not. Brand et al. (1993) and De Villiers et al. (2002) and Brundyn (2002) similarly found that lambs receiving creep feed had a higher live weight at weaning than lambs not receiving a creep. Johnson \& Light (1965) also reported that creep feed could increase weaning weight over a shorter period of time. Yet, in contract, Thomas \& Knott (1989) found that creep feed allocated to lambs had no effect $(P>0.05)$ on the live weight change of lambs from birth to weaning.

The birth status (single/twins) of the lambs, in this study, had no effect $(P>0.05)$ on the weight of the lambs at weaning. Bathaei \& Leroy (1998) and Greeff et al. (2003) indicated that birth status had a significant effect on the weaning weight of the lambs.

Growth curves for both the ewes and lambs are presented in Figures 2(a) and (b), respectively. Figure 2(a) illustrates the live weight changes (LWC) of lambs that received creep or not. The lambs that received creep feed showed a significant difference $(P<0.01)$ in LWC from the second to the tenth week of the experimental period. Weight changes of the ewes whose lambs received creep feed or not are illustrated in Figure 2(b). During the first 5 weeks of the experiment, creep feed had no significant effect on the weight change of the ewes. In week 5 a gradual increase in the live weight of the ewes can be observed. At this stage the lambs had the ability to utilise creep feed together with pasture, lowering milk demand from the ewe. This resulted in a positive effect on the live weight changes of the ewes from the fifth week. A $0 \%$ mortality rate occurred over the study period.

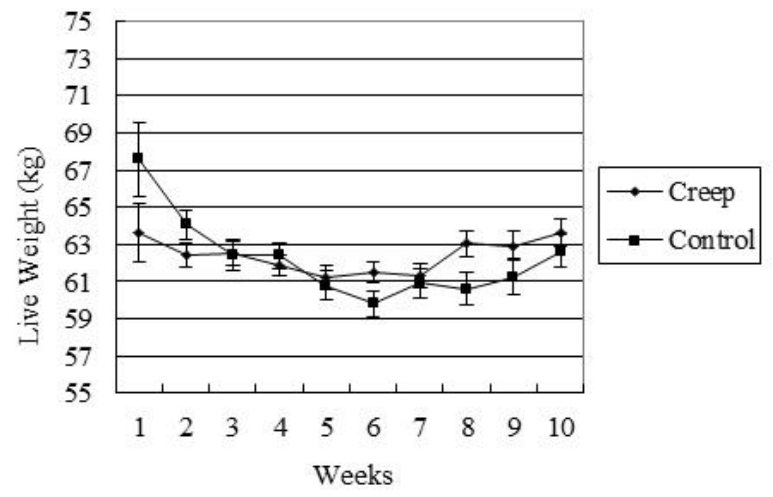

(a)

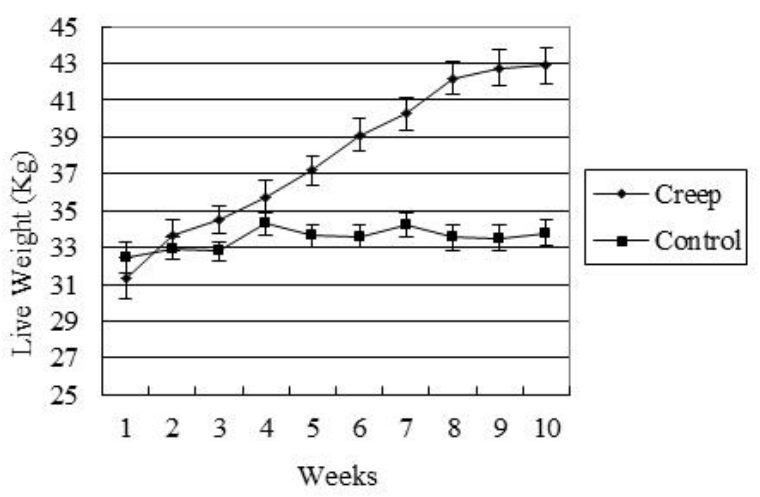

(b)

Figure 2 The live weight changes of (a) ewes and (b) lambs grazing kikuyu pasture supplemented or not with a creep feed for lambs.

\section{Conclusion}

This study showed that creep feeding to lambs is beneficial in terms of increasing final live weight of lambs. Creep feed increased the weaning weight of lambs, but did not significantly increase the live weight of ewes in all cases. Although not directly comparable, the results show that growth rate response of sheep and lambs differed when they had access to grazing pastures that differ in quality, such as kikuyu and medics pastures. A higher level of creep feed was also allocated to lambs grazing the kikuyu pasture. Creep feed is thus a management practice that can increase weaning weights of lambs substantially, although it is very important that quality and palatability must be ensured to obtain the required utilisation levels. However, the quality and type of pasture of the pasture, amount of creep feed provided, as well as meat and feed prices will determine the level of profitability of the practice.

\section{Acknowledgements}

The authors would like to thank the Western Cape Agricultural Research Trust for partly funding the project.

\section{References}

Aitchison, E., 1988. Cereal straw and stubble as sheep feed. J. Agric. W. Aust. 29, 96-101. 
Bathaei, S.S. \& Leroy, P.L., 1998. Genetic and phenotypic aspects of the growth curve characteristics in Mehraban Iranian fat-tailed sheep. Small Rumin. Res. 29, 261-269.

Brand, T.S., Van der Merwe, G.D. \& Young, D., 1993. Evaluering van verrykte gars en 'n kommersiële dieet as kruipvoer vir lammers. Elsenburg J, 4-6 (in Afrikaans).

Brand, T.S., Van der Merwe, G.D. \& Coetzee, J., 1999. Performance and nutritional status of lambs receiving either protein-enriched whole barley, creep pellets or no creep feed while grazing a dryland mixed grass pastures. In: Elsenburg Abstracts of Progress Reports, pp. 155-168.

Brundyn, L., 2002. The utilisation and supplementation to stubble lands for South Africa Mutton Merino ewes. MSc (Agric) thesis. University of Stellenbosch, South Africa.

Cloete, S.W.P., Greeff, J.C. \& Lewer, R.P., 2001. Environmental and genetic aspects of survival and early liveweight in Western Australian Merino sheep. S. Afr. J. Anim. Sci. 31, 123-130.

Coetzee, J., 2011. Kruipvoeding: Ononderhandelbaar vir winsgewende skaapproduksie. Dorper Nuus 2011, 21-26 (in Afrikaans).

De Villiers, J.F., 1991. Agricultural Production Guidelines for Natal: Elementary concepts of sheep nutrition, Compiled by Department of Agricultural Development: Natal Region.

De Villiers, J.F., 1997. Riglyne vir Landbouproduksie in KwaZulu-Natal: Elementêre konsepte van skaapvoeding. Saamgestel deur KwaZulu-Natal Departement van Landbou: Natalstreek (In Afrikaans).

De Villiers, J.F., Botha, W.A. \& Smith, M.F., 1993. The effect of stocking rate on the performance of ewes and lambs on Italian ryegrass. S. Afr. J. Anim. Sci. 23, 43-50.

De Villiers, J.F., Dugmore, T.J. \& Wandrag, J.J., 2002. The value of supplementary feeding to pre-weaned and weaned lambs grazing Italian ryegrass. S. Afr. J. Anim. Sci. 32, 30-37.

Greeff, J., Davidson, R. \& Skerrit, J., 2003. Genetic relationships between carcass quality and wool production traits in Australian Merino rams. Proc. Assoc. Advmnt. Anim. Breed. Gen. 15, 330-333.

Johnson, C.L. \& Light, M.R., 1965. Creep feeding lambs before pasture grazing. N. Dakota Farm Res. 23, 18-19.

Snyman, M.A. \& Olivier, W.J., 2002. Correlations of subjectively assessed fleece and conformation traits with production and reproduction in Afrino sheep. S. Afr. J. Anim. Sci. 32, 88-96.

Statgraphics, 2005. Statgraphics Centurion XV (Statpoint, inc.), www.statgraphics.com.

Thomas, V.M. \& Knott, R.E., 1989. Influence of creep feed on lamb performance during a drought. Sheep Res. J. 5, 1-4.

Weston, R.H. \& Hogan, J.P., 1986. Nutrition of Herbage-fed ruminants. Pastural industries of Australia, Sydney University Press, Sydney Australia. pp. 233-268. 